\title{
PENGEMBANGAN MODEL PEMBELAJARAN FISIKA UMUM BERBASIS PENDIDIKAN KARAKTER DI PROGRAM STUDI PENDIDIKAN FISIKA FMIPA UNIMED
}

\author{
Derlina, Tri Harsono dan Sabani \\ Fakultas matematika dan Ilmu Pengetahuan Alam Universitas Negeri Medan \\ derlina.nst@gmail.com; triharsonounimed@gmail.com; \\ bani.physics@gmail.com
}

\begin{abstract}
Abstrak. Tujuan utama penelitian ini adalah untuk meningkatkan karakter dan hasil belajar mahasiswa yang meliputi: pembelajaran berdasarkan masalah, pembelajaran kooperatif dengan berbagai tipe, dan inquiry training, melalui penyusunan perangkat pembelajaran untuk beberapa komptensi dasar mata kuliah Fisika Umum dengan model-model pembelajaran berbasis karakter. Jenis penelitian adalah penelitian pengembangan. Perangkat pembelajaran yang disusun meliputi (1) silabus, (2) rencana pelaksanaan pembelajaran (RPP), (3) bahan ajar, (4) lembar kerja mahasiswa (LKM), dan (5) pedoman/alat evaluasi. Target khusus yang ingin dicapai adalah (1) peningkatan hasil belajar mahasiswa, dan (2) mengembangkan karakter mahasiswa antara lain sikap jujur, tanggung jawab, disiplin, berlaku hormat, kerjasama, kemampuan berkomunikasi dan kreativitas.
\end{abstract}

Kata kunci: model pembelajaran, pendidikan karakter, hasil belajar

\section{DEVELOPMENT LEARNING MODEL GENERAL PHYSICS BASED CHARACTER EDUCATION IN STUDY PROGRAM PHYSICS EDUCATION FACULTY UNIMED}

\author{
Derlina, Tri Harsono and Sabani \\ Faculty of mathematics and Natural Sciences, State University of Medan \\ derlina.nst@gmail.com; triharsonounimed@gmail.com; \\ bani.physics@gmail.com
}

\begin{abstract}
The main objective of this research is to improve the character and student learning outcomes that include: problem based learning, cooperative learning with a variety of types, and inquiry training, through the development of learning tools for some basic competency courses of General Physics with models based learning character. This type of research is the development of research. The device includes structured learning (1) syllabus, (2) learning implementation plan (RPP), (3) instructional materials, (4) student worksheet (MFI), and (5) guidelines/evaluation tool. Specific targets to be achieved are (1) improvement of student learning outcomes, and (2) developing the character of students, among others, honesty, responsibility, discipline, true respect, teamwork, communication skills and creativity.
\end{abstract}

Keywords: learning model, character education, result study 


\section{PENDAHULUAN}

Pendidikan mempunyai peran yang strategis dalam menghasilkan sumber daya manusia seutuhnya baik sebagai individu maupun sebagai masyarakat. Makna dan tujuan pendidikan nasional tersebut mengamanahkan bahwa pendidikan berkewajiban menghasilkan peserta didik yang memiliki karakter yang baik.

Namun, gejala menunjukkan bahwa perilaku masyarakat menunjukkan terjadinya degradasi dalam pembentukan karakter bangsa Indonesia yang berazaskan Pancasila. Berbagai penyimpangan perilaku ditemukan dalam kehidupan sehari-hari. Banyak nilai-nilai luhur dari pancasila yang sudah tidak diindahkan lagi oleh masyarakat, terjadinya kemerosotan moral, memudarnya rasa nasionalisme dan cinta tanah. Menurut Husen, dkk (2010) degradasi nilainilai dan moral Pancasila tersebut tidak saja terjadi di kalangan masyarakat awam tetapi juga sudah merambah ke kepribadian para profesional, tokoh masyarakat, para terpelajar, para pendidik, elit politik, bahkan hingga para pemimpin bangsa dan Negara.

Pelaksanaan pembelajaran pendidikan karakter di Prodi Pendidikan Fisika sudah dicanangkan sejak lama yang diwujudkan dengan mengintegrasikan nilai-nilai softskill dalam setiap mata kuliah. Namun kenyataannya belum secara optimal mendukung pelaksanaan pendidikan karakter, pengembangan sofskill yang terkait dengan nilai-nilai moralitas belum maksimal sehingga iklim pendidikan karakter belum kondusif sepenuhnya. Salah satu hambatan yang dialami dosen adalah menentukan dan merancang model pembelajaran berbasis pendidikan karakter pada perkuliahan.

Padahal menurut Koesoema (2007) syarat utama keberhasilan pendidikan karakter adalah terletak pada peran dosen. Penanaman nilainilai dalam pendidikan karakter ditanamkan melalui model pembelajaran. Kegiatan pembelajaran yang mencerminkan pendidikan karakter hendaknya direncanakan dengan baik dalam perangkat pembelajaran. Berkaitan dengan hal di atas, dituntut kemampuan dosen merancang model pembelajaran yang dapat mengako- modasi pembelajaran yang sesuai substansi materi dan dapat menjadi wadah pengembangan nilai-nilai karakter.

Untuk dapat menerapkan pendidikan karakter ini, maka perlu disusun perangkat pembelajaran yang berbasis pendidikan karakter. Dalam Model pembelajaran yang berbasis pendidikan karakter ini memerlukan model, media, evaluasi dan metode yang bervariasi yang dapat menanamkan pilar pendidikan karakter yang diharapkan dimiliki oleh setiap mahasiswa melalui kegiatan perkuliahan.

Tujuan utama dari pelaksanaan penelitian ini adalah terwujudnya perangkat pembelajaran Fisika Umum dengan model-model pembelajaran berbasis karakter untuk meningkatkan karakter dan hasil belajar mahasiswa (yang meliputi: pembelajaran berdasarkan masalah, pembelajaran kooperatif dengan berbagai type, dan inquiry training). Semua tujuan ini direncanakan akan tercapai dalam 3 tahun.

\section{Pendidikan Karakter}

Karakter adalah perilaku yang dilandasi oleh nilai-nilai berdasarkan norma agama, kebudayaan, hukum/konstitusi, adat istiadat, dan estetika (Direktorat Pendidikan Dasar, 2011). Karakter adalah perwujudan dari cara berpikir dan bertindak seseorang dalam kehidupannya sebagai individu, sebagai anggota keluarga, masyarakat, bangsa dan Negara. Karakter sebagai bentuk perwujudan cara berpikir dan berperilaku sangat dipengaruhi oleh keluarga, lingkungan dan masyarakat. Karakter anak secara umum tidak jauh berbeda dari karakter ayah dan ibunya. Anak yang dididik dalam lingkungan keluarga militer biasanya memiliki karakter disiplin, anak yang didik dalam keluarga guru juga akan akan memiliki karakter menjadi panutan bagi orang lain. Dengan demikian jika anak-nak remaja kita saat ini diidentifikasi memiliki karakter yang kurang baik, pada dasarnya itulah potret keluarga saat ini, yakni kurang memiliki karakter. Adanya pengaruh lingkungan terhadap pembentukan karakter seseorang memberikan harapan bagi kita bahwa rendahnya karakter 
bangsa saat ini masih dapat diperbaiki melalui pencanagan pendidikan karakter. Karakter peserta didik dapat dibina dan dibentuk lewat pendidikan.

Scerenko dalam Samani dan Hariyanto (2012) mendefenisikan karakter sebagai atribut atau ciri-ciri yang membedakan dan membentuk ciri pribadi, ciri etis dan kompleksitas suatu kelompok atau bangsa. Karakter merupakan totalitas dari ciri pribadi sebagai ciri khas personality seseorang, yang terdiri dari nilai moral dan etis, nilai kejujuran, keberanian, integritas, dan reputasi yang baik, semua nilai tersebut di atas merupakan sebuah kualitas yang melekat pada kekhasan personal individu. Karakter begitu penting karena dengan memiliki karakter membuat individu dapat bertahan hidup menghadapi berbagai macam persoalan. Karakter menjadikan individu menjadi manusia yang tabah, tangguh, punya kepribadian yang mantap serta mempunyai rasa nasionalisme yang tinggi. Karakter disiplin, kerja keras, kreatif, bertanggung jawab, berpikir kritis, jujur merupakan karakter yang dimiliki oleh negaranegara maju. Bangsa Indonesia dengan falsafah Pancasila-nya harus mampu berdiri tegak sejajar di antara bangsa-bangsa lainnya. Dengan semangat Pancasila manusia Indonesia diharapkan menjadi manusia yang mempunyai karakter yang tangguh sehingga berani menatap masa depan Indonesia dengan lebih optimis.

Oleh karena itu munculnya keinginan untuk meningkatkan karakter masyarakat Indonesia adalah merupakan suatu keharusan, karena jika terlena maka Indonesia akan menjadi Negara terbelakang dan akan ditindas oleh negara-negara yang lebih maju. Pendidikan karakter mempunyai makna sebagai segala sesuatu upaya yang dapat dilakukan secara berencana dengan sungguh-sungguh sehingga dapat mengasilkan peserta didik yang berperilaku sebagai insan kamil, yakni menjadi manusia yang beriman dan bertakwa kepada Tuhan Yang Maha Esa, berakhlak mulia, sehat, berilmu, cakap, kreatif, mandiri, dan menjadi warga negara yang demokratis serta bertanggung jawab. Karakter dapat terbentuk dalam diri peserta didik melalui proses pemberian tuntunan dan proses keteladanan. Kakakter tertanam pada diri peserta didik dengan meneladani pendidik yang menunjukkan perilaku jujur, disiplin, bertanggung jawab, peduli dan religius. Pendidikan karakter menurut Samani dan Hariyanto (2012) bukan merupakan sesuatu yang diwariskan, tetapi sesuatu yang dibangun secara berkesinambungan hari demi hari melalui pikiran dan perbuatan, pikiran demi pikiran, tindakan demi tindakan.

Pembangunan karakter menurut Zubaedi (2012) merupakan upaya penanaman kecerdasan dalam berpikir, penghayatan dalam bentuk sikap, pengamalan dalam bentuk perbuatan yang sesuai dengan nilai-nilai luhur pancasila. Oleh karena itu pendidikan karakter perlu proses, teladan, pembiasaan atau pembudayaan dalam lingkungan peserta didik dalam lingkungan sekolah, keluarga, masyarakat bangsa dan Negara.

Pendidikan karakter di Universitas Negeri Medan wajib bermuara pada pembentukan manusia Indonesia seutuhnya. Salah satu perwujudan pendidikan karakter tersebut adalah dengan diintegrasikannya nilai-nilai karakter ke dalam semua mata kuliah. Pengintegrasian nilai-nilai karakter mahasiswa melalui mata kuliah dilakukan dengan mengimplementasikan model-model pembelajaran yang tepat sesuai dengan karakter yang akan dikembangkan. Menurut Lickona (1991) agar pendidikan karakter berjalan dengan efektif pendidik sebaiknya menggunakan berbagai model dan metode pembelajaran yang memiliki instructtional effect maupun nurturant effect dalam menumbuh kembangkan karakter pada diri peserta didiknya.

\section{Model-model Pembelajaran Pakem Berbasis Karakter}

Model-model pembelajaran dengan pendekatan Pembelajaran Aktif Kreatif Efektif dan Menyenangkan (Pakem) berbasis karakter adalah model pembelajaran yang memiliki ciri-ciri: a) berpusat pada mahasiswa, b) berbasis kompetensi, c) dosen bukan sumber satu-satunya 
Derlina, Harsono, T., dan Sabani: Pengembangan Model Pembelajaran Fisika Umum Berbasis Pendidikan Karakter di Program Studi Pendidikan Fisika FMIPA Unimed.

sebagai sumber belajar serta d) dosen berperan sebagai fasilitator. Model pembelajaran yang digunakan dalam penelitian ini adalah:

\section{Model Pembelajaran Kooperatif}

Pembelajaran kooperatif merupakan suatu model pembelajaran di mana mahasiswa belajar dalam kelompok-kelompok kecil yang memiliki tingkat kemampuan berbeda. Dalam menyelesaikan tugas kelompok, setiap anggota saling bekerja sama dan membantu untuk memahami suatu bahan pembelajaran. Belajar belum selesai jika salah satu teman dalam kelompok belum menguasai bahan pembelajaran.

Selain unggul dalam membantu siswa memahami konsep-konsep sulit, model ini sangat berguna untuk membantu siswa menumbuhkan kemampuan kerjasama, berikut langkahlangkah pembelajaran kooperatif (Ibrahim, 2000). Model pembelajaran kooperatif terdiri dari 6 fase yaitu: (1) Menyampaikan tujuan dan memotivasi mahasiswa, (2) Menyajikan informasi, (3) Mengorganisasikan mahasiswa ke dalam kelompok-kelompok belajar, Membimbing kelompok bekerja dan belajar, (5) Evaluasi dan (6) Memberikan penghargaan.

Walaupun prinsip dasar koopertif tidak berubah, terdapat 4 variasi dari model tersebut. 4 model yang merupakan bagian dri kumpulan strategi bagi dosen seperti model STAD (Student Team Achievement Division), Jigsaw, GI (Group Investvigasi), dan model Struktural (Ibrahim, 2000).

\section{Model Pembelajaran Berdasarkan Pemecahan Masalah}

Pembelajaran Berdasarkan Masalah secara garis besarnya untuk meyakinkan mahasiswa kedalam suatu masalah yang otentik dan bermakna yang dapat memberikan kemudahan kepada mereka untuk melakukan penyelidikan dan inkuiri. Peran dosen dalam PBI adalah mengajukan masalah, memfasilitasi penyelidikan dan dialog mahasiswa serta mendukung belajar mahasiswa. PBI diorganisasikan di sekitar situasi kehidupan nyata yang menghindari jawaban sederhana dan mengundang berbagai pemecahan yang bersaing. Adapun ciri-ciri utama PBI melipui suatu pengajuan pertanyaan atau masalah, suatu pemusatan antar disiplin, penyelidikan autentik, kerja sama menghasilkan karya dan peragaan.

\section{Model Pembelajaran Inquiry Training}

Model pembelajaran inquiry training adalah pembelajaran yang dirancang dengan rangkaian kegiatan yang melibatkan mahasiswa secara langsung melakukan proses-proses ilmiah untuk mencari dan menyelidiki suatu masalah yang menarik perhatiannya. Langkah pengimpelementasian model pembelajaran inquiry training secara operasional di ruang kelas dilakukan dengan fase sebagai berikut: (1) Menyajikan masalah, (2) Mengumpulkan dan memverifikasi data, (3) Eksperimen, (4) Mengorganisasi data, merumuskan dan menjelaskan dan (5) Menganalisis proses inkuiri.

\section{METODE PENELITIAN \\ Rencana Penelitian}

Penelitian ini dirancang berlangsung selama tiga tahun dengan tahapan sebagai berikut:

\section{Kegiatan Pengembangan Pada Tahun I (2014)}

\section{a. Penetapan materi pelajaran}

Materi pelajaran yang ditetapkan adalah materi pelajaran Fisika Umum sesuai dengan kurikulum yang berlaku yaitu Kurikulum Berbasis Kompetensi (KBK) Sistim Blok.

\section{b. Analisis kebutuhan}

Kegiatan yang dilakukan pada tahap ini adalah (1) menganalisis buku-buku atau bahan ajar Fisika Umum, (2) mengamati dan menganalisisi kegiatan pembelajaran Fisika Umum yang dilakukan oleh dosen di kelas, (3) menganalisis model-model pembelajaran yang digunakan serta kendala-kendala yang dialami dosen dalam pembelajaran Fisika Umum, dan (4) mengidentifikasi sumber-sumber belajar.

\section{c. Pengembangan perangkat pembelajaran}

Pada tahap ini dilakukan kegiatan menyusun draf perangkat pembelajaran dengan model-model pembelajaran berbasis karakter yang sesuai dengan tujuan materi pelajaran. 
Derlina, Harsono, T., dan Sabani: Pengembangan Model Pembelajaran Fisika Umum Berbasis Pendidikan Karakter di Program Studi Pendidikan Fisika FMIPA Unimed.

\section{Kegiatan Pengembangan Pada Tahun II} (Tahun 2015)

Pada tahun II dilakukan uji coba draf perangkat pembelajaran dengan tahapan:

a. Evaluasi oleh Dosen Fisika Umum, ahli isi dan ahli teknologi pembelajaran

Draf perangkat 1 yang dihasilkan pada tahun I dievaluasi oleh (1) 1orang Dosen Fisika Umum, (2) dosen ahli isi dan ahli teknologi pembelajaran: 1 orang ahli isi, dan 1 orang ahli teknologi pembelajaran yang kesemuanya berkualifikasi Doktor. Penilaian dilakukan dengan lembar pedoman penilaian oleh dosen dan ahli. Setelah dilakukan penilaian dilakukan revisi dan dihasilkan Draf Perangkat 2.

\section{b. Uji kelompok kecil}

Draf perangkat 2, diuji pada kelompok kecil mahasiswa. Uji ini dilakukan pada empat puluh orang mahasiswa. Hasil pada tahap ini adalah Draf Perangkat 3.

\section{c. Uji kelas}

Draf perangkat 3 diuji di dalam kelas dengan menggunakan rancangan penelitian tindakan kelas (PTK).

\section{d. Analisis data}

Data yang diperoleh dianalisis secara deskriptif. Tingkat kelayakan dan kriteria revisi produk menggunakan pedoman pada Tabel 1 .

Tabel 1. Rentang Skor, Tingkat Kelayakan, dan Kriteria Revisi

\begin{tabular}{ll}
\hline $\begin{array}{l}\text { Rentang Rata- } \\
\text { Rata Skor }\end{array}$ & $\begin{array}{l}\text { Tingkat Kelayakan dan } \\
\text { Kriteria Revisi }\end{array}$ \\
\hline $4,0-5,0$ & Sangat layak, tidak direvisi \\
$3,0-3,9$ & Layak, tidak direvisi \\
$2,0-2,9$ & Tidak layak, direvisi \\
$1,0-1,9$ & Sangat tidak layak, direvisi \\
\hline
\end{tabular}

- Penelitian Eksperimental pada Tahun III (Tahun 2011)

Untuk menguji keunggulan komparatif perangkat pembelajaran dengan model-model pembelajaran berbasis karakter dalam meningkatkan hasil belajar dan karakter mahasiswa, dilakukan penelitian eksperimental sebagai berikut.

\section{a) Menatapkan rancangan penelitian}

Desain penelitian yang digunakan adalah rancangan penelitian eksperimental semu Pretest-Postest Nonequivalent Control Group Design.

b) Instrumen pengumpulan data

- Data hasil belajar Fisika Umum dikumpulkan dengan menggunakan tes tulis obyektif.

- Data karakter sikap jujur, tanggung jawab, kreativitas, berlaku hormat, kerjasama, kemampuan berkomunikasi dan disiplin di ukur dengan lembar observasi.

\section{c) Analisis data}

Teknik analisis data menggunakan analisis deskriptif dan analisis kovarian multivariate (MANCOVA). Analisis kovarian multivariate (MANCOVA) digunakan untuk menguji perbedaan hasil belajar mahasiswa (kompetensi dan karakter). Sebagai kovariat dalam analisis ini adalah skor hasil tes awal bentuk tes obyektif. Sebelum uji MANCOVA dilaksanakan, terlebih dahulu dilakukan uji normalitas data dan uji homogenitas varian antar kelompok. Uji normalitas data digunakan statistik KolmogorovSmirnov dan Shapiro-Wilk. Uji homogenitas antar kelompok menggunakan Levene's Test dan Box's Test. Sebagai tindak lanjut dari uji MANCOVA, adalah uji signifikansi perbedaan nilai rata-rata variabel tergantung antar kelompok.

\section{HASIL PENELITIAN DAN PEMBAHASAN}

Capaian yang ingin didapatkan pada tahun pertama ini adalah tersusunnya satu draft perangkat pembelajaran mata kuliah Fisika Umum dengan model-model pembelajaran berbasis karakter untuk meningkatkan hasil belajar dan karakter mahasiswa. Berdasarkan kegiatan yang telah dilakukan maka telah disusun sejumlah perangkat pembelajaran yang berbasis pengembangan karakter dengan menggunakan 3 model pembelajaran yang meliputi: pembelajaran berdasarkan masalah, pembelajaran kooperatif dengan berbagai type, dan inquiry training). 


\section{Perangkat Pembelajaran Fisika Umum}

\section{- Silabus}

Sebagai satu acuan penting dalam perangkat pembelajaran maka silabus merupakan satu hal penting yang harus dipersiapkan untuk mencapai tujuan perkuliahan yang sudah ditetapkan. Dengan tersedianya silabus, maka garis besar kegiatan pembelajaran sudah tergambar dan menjadi arahan untuk kegiatan perkuliahan yang akan dilaksanakan.

\section{- Rencana Pelaksanaan Pembelajaran (RPP)}

RPP mengarahkan secara operasional suatu kegiatan perkuliahan sejak pembukaan hingga penutupan. Aktivitas apa saja yang akan dimunculkan dalam satu kegiatan perkuliahan tertera dalam satu RPP. Berdasarkan hasil kegiatan yang dilakukan telah disusun satu perangkat RPP mata kuliah Fisika Umum yang aktivitasnya pada kegiatan inti mengacu kepada 3 model pembelajaran yang diasumsikan akan menghasilkan produk berupa terbentuknya karakter-karakter seperti yang telah diajukan dalam tujuan penelitian.

\section{- Bahan Ajar}

Bahan ajar merupakan satu bagian penting yang harus dipersiapkan setiap dosen sebelum memulai aktivitas perkuliahan. Bahan ajar mencakup sejumlah materi atau konsepkonsep yang dapat diacu oleh peserta didik dalam mencapai tujuan perkuliahan. Bahan ajar yang disusun medngacu kepada berbagai sumber, ulasan beberapa ahli maupun ulasan dari pengalaman penulis selama bertugas menjadi dosen di FMIPA Unimed. Perpaduan sejumlah referensi ini menghasilkan satu produk dalam bentuk bahan ajar Fisika Umum.

\section{- Lembar Kerja Mahasiswa (LKM)}

LKM meruapakan satu bagian penting dalam KBM. Dengan adanya LKM, mahasiswa dapat melakukan satu aktivitas untuk mencapai tujuan perkuliahan yang memiliki kecenderungan seragam, serentak dan dapat dilakukan dalam jumlah besar (satu kelas) dengan target ketercapaian tujuan yang cenderung seragam, karena mengacu kepada pedoman yang sama di kelas yang sama pada waktu yang sama dan melakukan prosedur kerja yang sama serta dipandu oleh dosen yang sama, sehingga upaya untuk mentransfer sejumlah pengetahuan/ kompetensi target kepada mahasiswa akan tercapai dalam jumlah yang lebih besar.

\section{- Pedoman/alat evaluasi}

Untuk mengetahui apakah suatu kegiatan telah mencapai tujuannya, maka diperlukan satu alat ukur yang dapat mengukur ketercapaian tersebut. Alat ukur yang digunakan dalam kegiatan ini adalah tes yang didisain dalam beberapa bentuk seperti tes lisan, tulisan dan tes kinerja. Tes yang disusun diarahkan kepada penguasaan materi (kognitif), perubahan perilaku (tes afektif) dan keterampilan bekerja dengan menggunakan tes kinerja.

\section{Model Pembelajaran Berbasis Karakter Pembelajaran berdasarkan masalah}

Pembelajaran berbasis masalah ini dilakukan dengan sejumlah aktifitas yang sesuai dengan sintak-sintak yang telah disusun. Aplikasi dari sintak-sintak ini dalam KBM akan melatihkan peserta didik dalam satu kegiatan belajar yang menggiringnya untuk melakukan atau menerapkan satu perbuatan yang mengarah kepada perbuatan-perbuatan baik (soft skill). Beberapa karekater yang diharapkan akan menjadi pembiasaan dengan adanya aplikasi model belajar ini antara lain: tanggung jawab, kreatif, inovatif, kemampuan bekerjasama dan berkomunikasi serta rasa percaya diri. Karakter ini menjadi terbiasa dilakukan karena sering dan berulang ulang dilakukan dalam KBM di ruang kelas ataupun di luar kelas.

\section{Pembelajaran kooperatif dengan berbagai type}

Pembelajaran kooperatif diaplikasikan dengan satu asumsi bahwa aktifitas yang terjadi di dalama satu KBM tidak berjalan karena kurangnya partisipasi belajar dari peserta didik. Kalaupun ada aktifitas atau partisipasi belajar hanya tertumpu pada beberapa peserta didik saja. Sementara itu dalam tujuan KBM diharapkan agar semua peserta didik aktif dan berpartisipasi dalam belajar. Untuk itu aplikasi 
pembelajaran kooperatif menjadi satu alternatif untuk dilaksanakan.Dengan aplikasi model kooperatif dalam satu kegiatan belajar, maka aktifitas belajar diharapkan akan bergeser dari dominansi mahasiswa pintar kepada mahasiswa lainnya. Tadinya hanya mahasiswa tertentu saja yang aktif melakukan pembelajaran, akan tetapi dengan model kooperatif ini memaksa peserta didik harus berbicara dan mengajukan pendapatnya dalam satu forum diskusi. Langkah awal berbicara inilah yang diharapkan menjadi titik balik munculnya keberanian untuk berbicara dalam satu forum diskusi.

Pembelajaran kooperatif ini dilakukan dengan sejumlah aktifitas yang sesuai dengan sintak-sintak yang telah disusun. Aplikasi dari sintak-sintak ini dalam KBM akan melatihkan peserta didik dalam satu kegiatan belajar yang menggiringnya untuk melakukan atau menerapkan satu perbuatan yang mengarah kepada perbuatan-perbuatan baik (soft skill). Beberapa karekater yang diharapkan akan menjadi pembiasaan dengan adanya aplikasi model belajar ini antara lain: kerjasama, terbuka, tenggang rasa, menghargai pendapat orang lain, berani berpendapat, santun dalam berbicara, analitis, kritis, logis, kreatif dan dinamis. Karakter ini menjadi terbiasa dilakukan karena sering dan berulang ulang dilakukan dalam KBM di ruang kelas ataupun di luar kelas.

\section{Inquiry Training}

Pembelajaran dengan inquiry training dilakukan dengan cara membiasakan mahasiswa melakukan latihan mandiri dengan melakukian sejumlah penelitian yang berkaitan dengan topik atau tema tema perkuliahan yang akan dilaksanakan. Inquiry training membiasakan siswa melakukan proses belajar dengan penuh kesadaran dan tanggung jawab untuk memecahkan satu permasalahan dengan cara melakukan penelitian penelitian atau kegiatan kegiatan observasi yang dapat menjawab permasalahan yang diajukan. Dengan pembiasaan aplikasi model perkuliahan ini diharapkan akan memunculkan beberapa karakter seperti: rasa ingin tahu, menelusuri sumber sumber ilmu secara mandiri, tidak tergantung kepada orang lain dalam memecahkan satu permasalahan. Pembiasaan model ini dalam kegiatan perkuliahan diharapkan akan menghasilkan lulusan mandiri dengan daya juang yang tinggi, kreativitas, dan jiwa kerjasama serta merasakan bahwa belajar itu adalah sebuah kebutuhan bukannya sebuah beban atau pemaksaaan dari pendidik (dosen ) kepada peserta didik.

\section{Pembahasan Penelitian}

Terwujudnya draft perangkat pembelajaran Fisika Umum dengan model-model pembelajaran berbasis karakter untuk meningkatkan karakter dan hasil belajar mahasiswa (yang meliputi: pembelajaran berdasarkan masalah, pembelajaran kooperatif dengan berbagai type, dan inquiry training) merupakan target utama tahun pertama pelaksanaan penelitian ini.

Draft yang mencakup persiapan perkuliahan yang mengaplikasikan 3 model pengembangan karakter ini akan diaplikasikan dalam uji coba real teaching mata kuliah Fisika Umum di FMIPA Unimed. Namun sebelum draft ini final masih diperlukan sejumlah kritisi dan masukan dari berbagai nara sumber agar draft ini menjadi lebih baik. Berdasarkan hasil revisi dari masukan dan saran-saran tersebut akan disusun satu model pengembangan perkuliahan berbasis karakter pada mata kuliah Fisika Umum.

Keterkaitan antara persiapan perkuliahan, keterampilan memberi kuliah serta evaluasi terhadap pelaksanaan perkuliahan merupakana satu mata rantai yang akan mengukur keberhasilan suuatu kegiatan belajar. Alat ukur yang digunakan sangat tergantung kepada komponen mana yang akan diukur seperti: kognitif (ranah pengetahuan), afektif (ranah sikap yang menjadi target utama pengembangan karakter dan psikomotorik yang diharapkan akan mengembangkan keterampilan mahasiswa dalam mengaplikasikan pengetahuannya di lingkungan kerja atau di masyarakatnya. Untuk itu keberadaan model pembelajaran yang mengarah kepada pembentukan 
Derlina, Harsono, T., dan Sabani: Pengembangan Model Pembelajaran Fisika Umum Berbasis Pendidikan Karakter di Program Studi Pendidikan Fisika FMIPA Unimed.

karakter yang baik merupakan satu tuntutan yang harus dipersiapkan, sehingga dapat dikembangkan menjadi satu pola perkuliahan yang dapat diaplikasikan dalam perkuliahanperkuliahan lainnya di kelas yang berbeda atau pada mata kuliah yang berbeda.

\section{SIMPULAN}

Terwujudnya draft perangkat pembelajaran Fisika Umum dengan model-model pembelajaran berbasis karakter untuk meningkatkan karakter dan hasil belajar mahasiswa (yang meliputi: pembelajaran berdasarkan masalah, pembelajaran kooperatif dengan berbagai type, dan inquiry training) merupakan target utama tahun pertama pelaksanaan penelitian ini.

\section{UCAPAN TERIMA KASIH}

Terimakasih yang tulus disampaikan kepada Pimpinan Unimed yang telah membantu dalam penyediaan dana untuk pelaksanaan penelitian dan semua pihak yang turut membantu sehingga penelitian dan penulisan laporan ini dapat diselesaikan.

\section{DAFTAR PUSTAKA}

Direktorat Jenderal Pendidikan Dasar. 2011. Pendidikan Karakter untuk membangun Karakter Bangsa. Jakarta: Kemdiknas.

Husen, A., Jakfar, M., dan Yuyus, K. 2010. Model Pendidikan Karakter Bangsa Sebuah Pendekatan monolitik di Universitas Negeri Jakarta. Jakarta: UNJ. Ibrahim, M., dkk. 2000. Pembelajaran Kooperatif. Surabaya: Penerbit Unesa University Press.

Koesoema, AD. 2007. Pendidikan Karakter. Jakarta: Grasindo.

Lickona, T. 1991. Educating for Character. New York: Bantam Book.

Samani, Muchlas dan Hariyanto. 2012. Konsep dan Model Pendidikan Karakter. Bandung: Remaja Rosdakarya.

Zubaedi. 2012. Desain Pendidikan Karakter, Konsepsi dan Aplikasinya dalam Lembaga Pendidikan. Jakarta: Kencana Prenada Media Group. 